\title{
Celiac Disease with Dermatitis Herpetiformis Case Report
}

\section{Gabriel Samasca ${ }^{1 *}$, Adrian Baican ${ }^{2}$, Alexandru Pirvan ${ }^{3}$, Nicolae Miu ${ }^{3}$ and Doru Dejica ${ }^{4}$}

${ }^{1}$ Department of Immunology, University of Medicine and Pharmacy Cluj-Napoca, Romania

${ }^{2}$ Dermatology Clinic Cluj-Napoca Romania

3/Ind Pediatric Clinic Cluj-Napoca Romania

${ }^{4}$ IIIrd Medical Clinic Cluj-Napoca Romania

\section{Introduction}

Dermatitis herpetiformis (DH) is traditionally diagnostic by direct immunofluorescence (DIF) and histopathology punch. In DH there is granular IgA deposition along the dermoepidermal junction with concentration at the tips of the papillary dermis [1].

\section{Case Report}

A 9-year-old girl presented to dermatologist with a 9-month history of intensely pruritic vesicles on his elbows, buttocks and back and no gastrointestinal symptoms (Figure 1).

The dermatologist informed her parents that his clinical impression was $\mathrm{DH}$ and performed punch biopsies for DIF.

The DIF showed granular IgA deposition in the papillary dermis (Figure 2).
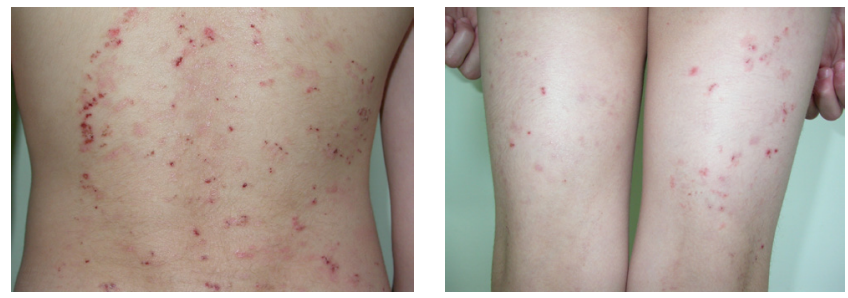

Figure 1: Dermatitis herpetiformis.
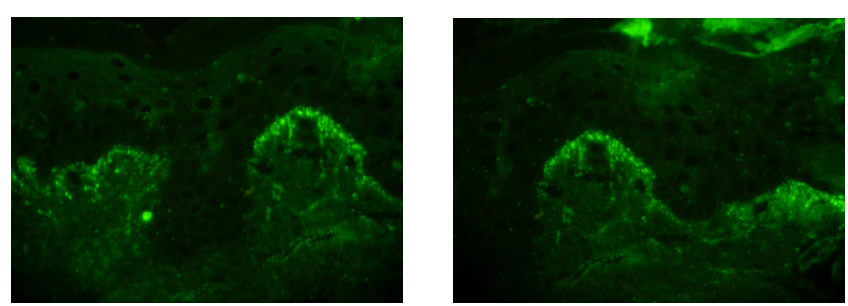

Figure 2: Direct immunofluorescence method (skin biopsy).
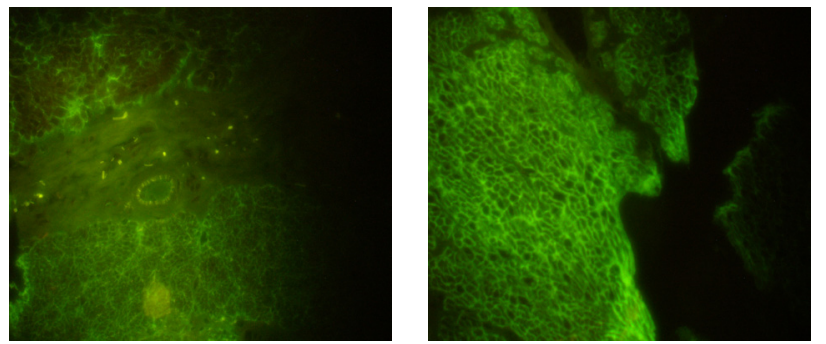

Figure 3: Indirect immunofluorescence method (monkey esophagus tissue).
We performed:

- ELISA testing: IgA tissue transglutaminase antibody testing was positive at $327 \mathrm{U} / \mathrm{ml}$ (negative $<25 \mathrm{U} / \mathrm{ml}$, positive $>25 \mathrm{U} / \mathrm{ml}$ ); IgA+IgG anti deamidated gliadin-derived peptides antibodies was positive at 124 $\mathrm{U} / \mathrm{ml}$ (negative $<15 \mathrm{U} / \mathrm{ml}$, positive $>15 \mathrm{U} / \mathrm{ml}$ ); IgA anti-Gliadin test was positive at $18 \mathrm{U} / \mathrm{ml}$ (negative $<15 \mathrm{U} / \mathrm{ml}$, positive $>15 \mathrm{U} / \mathrm{ml}$ ); IgG antiGliadin test was negative;

- Indirect immunofluorescence was positive on monkey esophagus (Figure 3).

- Other laboratory parameters: $\mathrm{IgM}=165 \mathrm{mg} / \mathrm{dl}$ (normal value 50 $260 \mathrm{mg} / \mathrm{dl}$ ); $\operatorname{IgA}=143 \mathrm{mg} / \mathrm{dl}$ (normal value $29-270 \mathrm{mg} / \mathrm{dl}$ ); $\mathrm{IgG}=1338$ $\mathrm{mg} / \mathrm{dl}$ (normal value 700-1650 mg/dl); C3=134 mg/dl (normal value 90-180mg/dl);

The patient was then referred to a gastroenterologist who confirmed the diagnosis of celiac disease (CD).

\section{Discussion}

Demonstration of IgA immune deposits in the dermal papillae has been the only acceptable criterion for the diagnosis of dermatitis herpetiformis. However, granular IgA deposition showed by DIF can appears in other dermatitis: IgA bullous dermatosis (LABD), along the cutaneous basement membrane zone [2]. Diagnostics by DIF required a good microscope and depends by experience of laboratory man [3].

A patient with $\mathrm{DH}$, diagnosed with LABD by DIF may not be started on a gluten-free diet and would be at risk for intestinal lymphoma.

Patients with DH produce IgA antibodies against endomysium. A number of studies have since shown anti-endomysial antibody to be a highly sensitive (90\%) and specific (96\%) marker for detecting untreated $\mathrm{DH}$ and $\mathrm{CD}$ [4]. Tissue translutaminase (tTG) is the major target antigen recognized by anti-endomysial antibodies [5]. Enzymelinked immunosorbent assay (ELISA) for IgA antibodies against tTG presented sensitivity and specificity comparable to EMA testing and no need for an animal substrate [6].

*Corresponding author: Gabriel Samaşca, Department of Immunology, Croitorilor Street, 19-21 No, "luliu Hațieganu" University of Medicine and Pharmacy ClujNapoca, Romania, E-mail: Gabriel.Samasca@umfcluj.ro

Received January 05, 2011; Accepted January 11, 2011; Published January 17, 2012

Citation: Samasca G, Baican A, Pirvan A, Miu N, Dejica D (2012) Celiac Disease with Dermatitis Herpetiformis Case Report. J Biomol Res Ther 1:e101. doi:10.4172/ jbmrt.1000e101

Copyright: @ 2012 Samasca G et al. This is an open-access article distributed under the terms of the Creative Commons Attribution License, which permits unrestricted use, distribution, and reproduction in any medium, provided the original author and source are credited. 
Citation: Samasca G, Baican A, Pirvan A, Miu N, Dejica D (2012) Celiac Disease with Dermatitis Herpetiformis Case Report. J Biomol Res Ther 1:e101. doi:10.4172/jbmrt.1000e101

Page 2 of 2

Therefore we suggest tTG-ELISA should replace DIF as a first step in $\mathrm{DH}$ diagnosis.

\section{Conclusions}

The case confirms again possibility association $\mathrm{DH}$ with asymptomatic CD.

\section{References}

1. Samaşca G, Băican A, Pîrvan A, Dejica D (2009) Dermatitis Herpetiformis. Romanian Journal of Medical Laboratory 4: 23-27.

2. Van L, Browning JC, Krishnan RS, Kenner-Bell BM, Hsu S (2008) Dermatitis herpetiformis: Potential for confusion with linear IgA bullous dermatosis on direct immunofluorescence. Dermatol Online J 14: 21.

3. Samaşca G, Băican A, Dejica D, Miu N (2009) Rare diseases: dermatitis herpetiformis. Description, laboratory diagnosis, stage results. Orvosi des Gzogzszereszeti Szemle Journal of Medicine and Pharmacy 55: 300-302.

4. Setty M, Hormaza L, Guandalini S (2008) Celiac disease: risk assessment, diagnosis, and monitoring. Mol Diagn Ther 12: 289-298.

5. Dieterich W, Laag E, Bruckner-Tuderman L, Reunala T, Karpati S, et al. (1999) Antibodies to tissue transglutaminase as serologic markers in patients with dermatitis herpetiformis. J Invest Dermatol 113: 133-136.

6. James SP (2005) This month at the NIH: Final statement of NIH Consensus Conference on Celiac disease. Gastroenterology 128: 6 . 